UDC 581.198:633.12

\title{
ORGANO-SPECIFIC ACCUMULATION OF PHENOLIC COMPOUNDS IN A BUCKWHEAT SEEDLINGS UNDER ALUMINIUM-ACID STRESS
}

\author{
O. E. SMIRNOV, A. M. KOSYAN, YU. V. PRYIMAK, \\ O. I. KOSYK, N. YU. TARAN \\ ESC "Institute of Biology and Medicine", \\ Taras Shevchenko National University of Kyiv, Ukraine; \\ e-mail:plantaphys@gmail.com
}

Received: 19 September 2020; Accepted: 17 December 2020

\begin{abstract}
Toxic effect of aluminum contamination is one of the causes of valuable crops yield loss all over the world. It is considered that plants' phenolic compounds play a key role in aluminium detoxification by chelation of aluminium ions in the aboveground part of aluminium-accumulating plants. However, recent evidence shows the chelating ligands involvement in both the internal and external aluminium detoxification in plants. The aim of the study was to determine the total phenolic compounds, flavonoids, anthocyanins accumulation and the activity of phenylalanine ammonia-lyase (PAL) as the key enzyme in phenolic compounds synthesis in seedlings of common (Fagopyrum esculentum Moench.) and tartary (Fagopyrum tataricum (L.) Gaertn.) buckwheat in response to the chronic aluminium-acid stress. It was recorded that addition of $50 \mu M$ $\mathrm{Al}_{2}\left(\mathrm{SO}_{4}\right)_{3} \cdot 18 \mathrm{H}_{2} \mathrm{O}$ to the nutrient medium led to the accumulation of phenolic compounds in all organs of both studied species on the tenth day of the plant exposure to stress. Species-specific and organ-specific accumulation of certain classes of phenylpropanoids was recorded. On the tenth day of stress, PAL activity was increased in the leaf tissues of both buckwheat species, but was decreased in common buckwheat root tissues and no statistically significant changes were observed in tartary buckwheat root tissues. Species and organ specificity of phenylpropanoids accumulation in the studied species is considered to be an adaptive reaction under conditions of aluminum stress.
\end{abstract}

Ke y wo rds: aluminium phytotoxicity, phenolic compounds, phenylalanine ammonia-lyase, Fagopyrum esculentum, Fagopyrum tataricum.

$\mathrm{P}$ lant organisms growing under unfavorable environmental conditions are constantly exposed to influence of different stress factors. Thereby during evolutionary development, plants developed a number of mechanisms that promote adaptation to various stress factors and underlie adaptive survival strategies. One or another strategy, in turn, exhibits possibilities of particular species' adaptive potential.

Protective adaptive mechanisms of plants under action of biotic and abiotic stressors are characterized by hefty plasticity and diverseness, but necessary elements for driving of such mechanisms are: activation of stress signaling - transduc- tion of the adaptive functionally important signals, cross-talking between different elaborate multilevel signaling systems and induction of stress-protective effects at the level of primary and secondary metabolism [1].

Given this, one of the tasks of the modern sustainable agriculture is interpretation and integration of data in the cell networks of genome, transcriptome, proteome and metabolome to provide the holistic picture of cumulative expression of organism's stress-induced response - forming a unite system of adaptive strategies or adaptome [2].

In recent years, wide experimental confirmation obtained the hypothesis in which the basis of

(C) 2021 Smirnov O. E. et al. This is an open-access article distributed under the terms of the Creative Commons Attribution License, which permits unrestricted use, distribution, and reproduction in any medium, provided the original author and source are credited. 
plant adaptive potential under stress is effective functioning of the protective antioxidant system, because free-radical damage of biomolecules (oxidative stress) is considered a nonspecific manifestation of any stressor influence [3].

The base of the antioxidant system is composed of the high-molecular antioxidants - various forms of superoxide dismutases, peroxidases, catalases (enzymes that scavenge free radicals) [4]. The antioxidant properties of the plant metabolites - lowmolecular antioxidants are actively studied, among them are carotenoids, ascorbic acid, polyamines, free amino acids, betaine, terpenoids [5], but the most attention is given to research on phenolic compounds as the free radicals scavengers [6].

It is known that the aluminium in solubilized form negatively affects plant organism disrupting the major structures and homeostatic processes of a plant cell: cell wall, plasma membrane composition and physicochemical properties, absorption of $\mathrm{Ca}^{2+}$ ions and support of calcium balance, signaling systems, dynamic changes of cytoskeleton, mitosis and DNA structure [7]. Toxic effect of aluminium in acidic soil (aluminium-acid stress) is the main reason of yield loss of valuable crops all over the world. Total yield loss because of aluminium-acid stress can reach over $50 \%$ [8].

Several studies have revealed that small organic compounds, such as organic acids and phenolic compounds play key roles in the uptake, translocation, accumulation, and internal detoxification of aluminium in different organs of aluminiumaccumulating plants [9]. The internal detoxification mechanisms include aluminium ions chelation in the cytosol by organic ligands, transportation and compartmentation in the vacuoles most often in the aboveground part of aluminium-accumulating species. However, recently accumulating evidence shows that chelating ligands play an important role in both the internal and external aluminium detoxification [10].

Aim of the study was to determine the organspecific peculiarities of accumulation of the low-molecular antioxidants and chelating ligands - phenolic compounds and their certain classes (flavonoids and anthocyanins) in response to simulation of the chronic aluminium-acid stress in seedlings of two species of buckwheat; to study the activity of phenylalanine ammonia-lyase (PAL) in different plant organs under aluminium toxicity.

\section{Materials and Methods}

Plant material and stress condition preparation. For analysis were used roots, hypocotyls and leaves of the 17-day old seedlings of two buckwheat species, Fagopyrum esculentum Moench. cv 'Rubra' and Fagopyrum tataricum (L.) Gaertn. cv 'Himalaicum'. Seeds were germinated in Petri dishes containing wet filter paper at $25{ }^{\circ} \mathrm{C}$. Two days after germination seedlings were transferred to pots $(300 \mathrm{ml})$ with sterilized sand that were kept under controlled conditions, at $25^{\circ} \mathrm{C}, 16 / 8 \mathrm{~h}$ (light/ dark) photoperiod and light intensity of about $200 \mu \mathrm{mol} \cdot \mathrm{m}^{-2} \cdot \mathrm{s}^{-1}$. 50\% Knop's solution (Acros Organics, Belgium) was used for plant nutrition (200 ml per pot). Aluminium-acid stress was simulated by adding aluminium in concentration of $50 \mu \mathrm{M}$ of the $\mathrm{Al}_{2}\left(\mathrm{SO}_{4}\right)_{3} \cdot 18 \mathrm{H}_{2} \mathrm{O}$ (Fisher Chemicals, USA) to the sand culture on the seventh day after germination, in this case the phosphorus was excluded from the solution to avoid sedimentation and $\mathrm{pH}$ was lowered to 4.5. The solution was renewed every day to maintain the medium acidity.

Phenolic compounds profiling and phenylalanine ammonia-lyase activity assay. Quantitative changes of total phenolic, flavonoid, anthocyanin content and PAL activity in the root, hypocotyl and leaf tissues were measured after ten days of plants exposure (DPE) to the chronic aluminium-acid stress with spectrophotometer UV-1800 "Shimadzu" (Japan).

For total phenolic content analysis was used Folin-Ciocalteu reagent (Acros Organics, Belgium) by the method [11]. Gallic acid (Acros Organics, Belgium) was used as a standard to make a calibration curve. Results were expressed in mg of gallic acid equivalents (GAE) per g of dry weight (DW). To determination flavonoid content $25 \mathrm{mg}$ of dried plant material were extracted in $1 \mathrm{ml}$ of absolute methanol during the day. From the resulting extract $50 \mu \mathrm{l}$ were taken for differential spectrophotometry using the $0.2 \%(\mathrm{w} / \mathrm{v})$ aqueous solution of zirconyl nitrate, $\mathrm{ZrO}\left(\mathrm{NO}_{3}\right)_{2} \cdot 2 \mathrm{H}_{2} \mathrm{O}$ (Fisher Chemicals, USA). Optical density was measured at $397.6 \mathrm{~nm}$ [12]. Rutin (Acros Organics, Belgium) as a dominant flavonoid was used as a standard to make a calibration curve [13]. Results were expressed in mg of rutin equivalents (RE) per g of dry weight (DW). To determination of the anthocyanin content was conducted by the method [14] with slight modifications. For calcula- 
tions there were used cyanidin-3-glucoside molar extinction coefficient and molecular weight.

PAL activity was measured by the Zucker assay [15] with our own modifications [16]. Spectrophotometric determination of enzyme activity was based on the change of optical density at $274 \mathrm{~nm}$ wavelength. Results were expressed in $\mu$ moles of cinnamic acid per minute per gram of protein $(\mu \mathrm{M}$ $\left.\mathrm{CA} \cdot \mathrm{min}^{-1} \cdot \mathrm{g}^{-1} \mathrm{PR}\right)$. Protein content was analyzed by the Bradford assay [17], using BSA as a standard (Acros Organics, Belgium).

Statistical analysis. The data were analyzed using Microsoft Excel 2010 Software and one-way ANOVA was applied. The results were processed by comparison of the mean \pm standard deviation $(\mathrm{M} \pm \mathrm{SD})$. The obtained data from combined analysis were subjected to the statistical analysis of variance and means were compared at 0.05 level according to Tukey test.

\section{Results and Discussion}

Addition of aluminium in concentration of $50 \mu \mathrm{M}$ to the nutrient media caused statistically significant increase in total phenolic content in all organs of common buckwheat seedlings compared to control on the tenth DPE (Fig. 1, A). Total phenolic content increased in roots by 19\% (15.16 mg GAE/g DW), in the hypocotyl tissues by $15 \%$ (34.35 mg GAE/g DW) and in the leaf tissues by 27\% (72.09 mg GAE/g DW). Similar tendency of the phenolic compounds accumulation in all organs after addition of $50 \mu \mathrm{M}$ of aluminium to the nutrient solution was noted for tartary buckwheat, but intensity of the response reaction to aluminium toxicity in synthesis and accumulation of phenolic compounds in this buckwheat species was much higher (Fig. 1, B). Total phenolic content increased on the tenth DPE in roots by $76 \%$ (33 mg GAE/g DW), in the hypocotyl tissues by $26 \%$ (40.01 mg GAE/g DW) and in the leaf tissues in 2 times (71.40 mg GAE/g DW).

On the tenth DPE with $50 \mu \mathrm{M}$ of aluminium flavonoid content (Fig. 2, A) increased only in the leaf tissues of common buckwheat species - by $46 \%$ (41.98 mg RE/g DW). In the hypocotyl tissues of this species flavonoid content remained at the level of control - $13.45 \mathrm{mg} \mathrm{RE} / \mathrm{g} \mathrm{DW}$, in this case in roots we recorded a sharp decrease in flavonoid content by $27 \%$ (4.56 mg RE/g DW) when aluminium was added. In the case of adding $50 \mu \mathrm{M}$ of aluminium to the nutrient solution flavonoid content in tartary buckwheat seedlings (Fig, 2, B) increased in the leaf and hypocotyl tissues by 58\% (36.37 mg RE/g DW) and 10\% (12.61 mg RE/g DW) respectively. In the root tissues of this species flavonoid content decreased in the presence of the toxicant on the tenth DPE by $61 \%$ (3.34 mg RE/g DW).

Anthocyanin content increased only in the hypocotyl tissues of common buckwheat seedlings (Fig. 3, A) and was $1.54 \mathrm{mg} / \mathrm{g} \mathrm{DW}-111.5 \%$ of the control content. Anthocyanin content in the leaf tissues remained at the level of control $-0.89 \mathrm{mg} / \mathrm{g}$ DW, and decreased in the root tissues by $64 \%(0.12 \mathrm{mg} / \mathrm{g}$ $\mathrm{DW})$. Adding of $50 \mu \mathrm{M}$ of aluminium to the nutrient solution did not cause any statistically significant increase in anthocyanin content in all studied organs of tartary buckwheat on tenth DPE (Fig. 3, B).
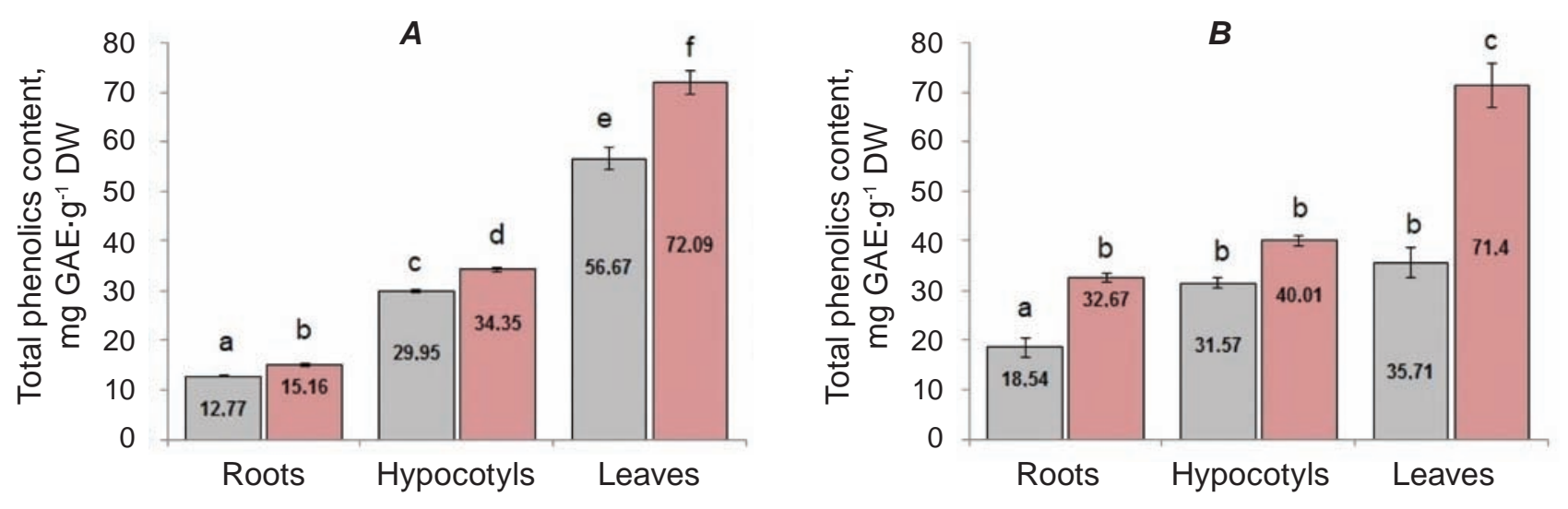

Fig. 1. Total phenolic compounds content in seedlings of common buckwheat (A) and tartary buckwheat (B) under aluminium-acid stress: $\square$ - control; $\square$-after 10 days of exposure to aluminium $(50 \mu M)$. Here and the next figures - columns followed by the same letter are not statistically different according to Tukey test $(P<0.05 \%)$. Vertical bars indicate to standard deviation $( \pm S D)$ 

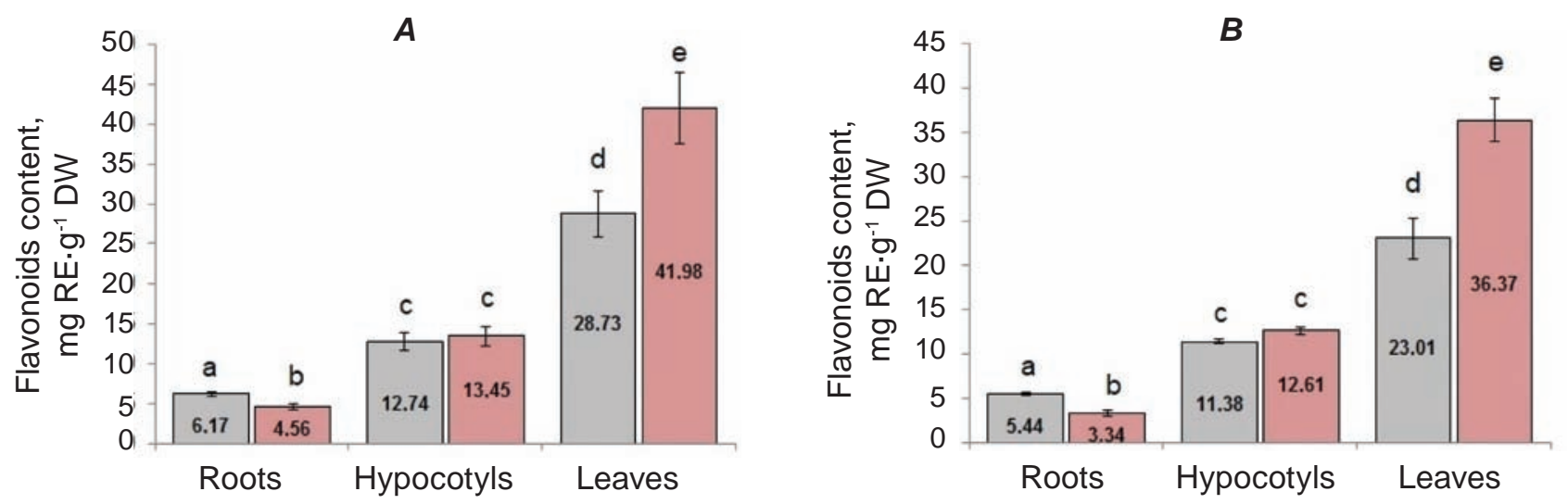

Fig. 2. Flavonoids content in seedlings of common buckwheat (A) and tartary buckwheat (B) under aluminium-acid stress: $\square$ - control; $\square$-after 10 days of exposure to aluminium (50 $\mu \mathrm{M})$
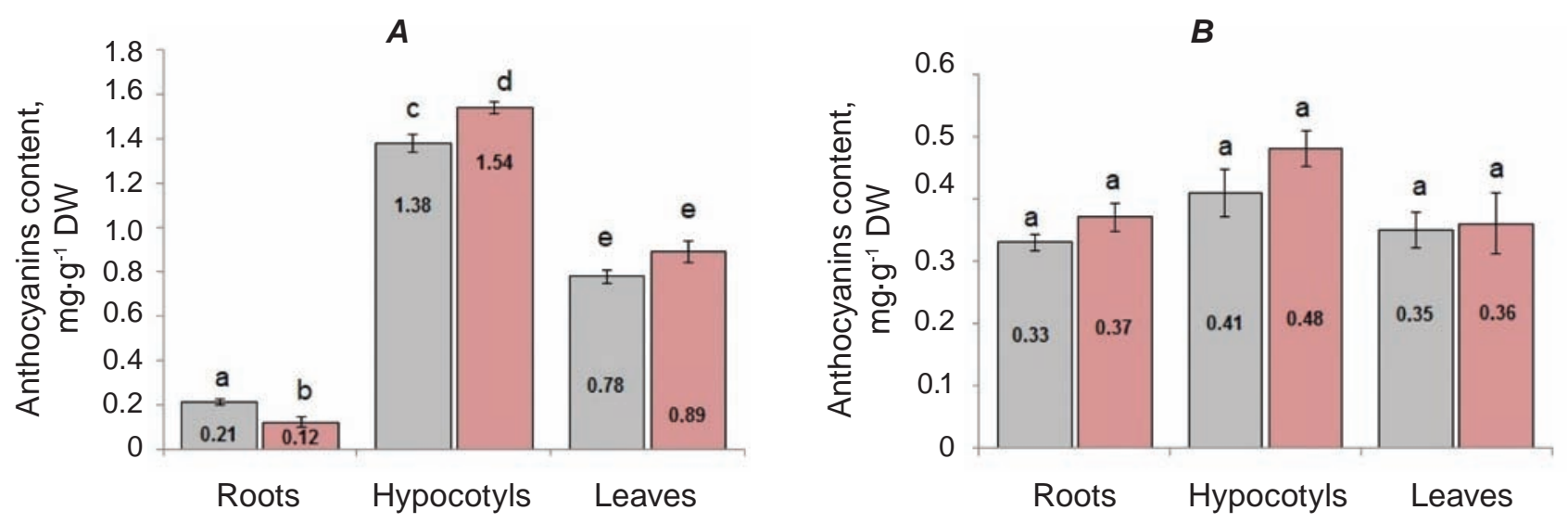

Fig. 3. Anthocyanins content in seedlings of common buckwheat (A) and tartary buckwheat (B) under aluminium-acid stress: $\square$ - control; $\square$-after 10 days of exposure to aluminium (50 $\mu \mathrm{M})$

During the study there was found that PAL activity in roots of common buckwheat was higher than control level from first till sixth DPE to aluminium presence in the nutrient medium (Fig. 4, A). PAL activity in the leaf tissues of the studied plants exceeded the control level from sixth until tenth DPE to the solution with the toxicant (Fig. 4, B).

During first DPE to aluminium-acid stress there was observed a tendency of increase of PAL activity in roots of the plants. Peak of the PAL activity in the root tissues was noted at the fourth DPE, activity of the studied enzyme was 2 times higher than the control level. Subsequently there was noticed a decrease in the activity, at the tenth day of exposure PAL activity declined by 58\% compared to the control. In the leaf tissues of plants grown in the presence of aluminium, there was observed a reverse tendency. PAL activity remained at level of the con- trol during first stages of stressor influence (first 4 days). On the sixth DPE PAL activity raised by $52 \%$ compared to the control, on the eighth and tenth DPE there were recorded maximum levels of the enzyme activity, it increased in 2-2.5 times.

The addition of aluminum exhibited an increase of PAL activity in the roots tissues of tartary buckwheat from first until eighth DPE (Fig. 4, C). The maximum level of PAL activity was recorded on fourth and sixth DPE - enzyme activity increased by 2.5 times relative to the control level. On the eighth DPE in roots tissues of plants that developed under conditions of aluminium-acid stress revealed a statistically significant increase in enzymatic activity by $35 \%$, with subsequent decrease of activity to the constitutive level on the tenth DPE.

Investigation of PAL activity in leaves tissues of tartary buckwheat plants, exposed on solution 

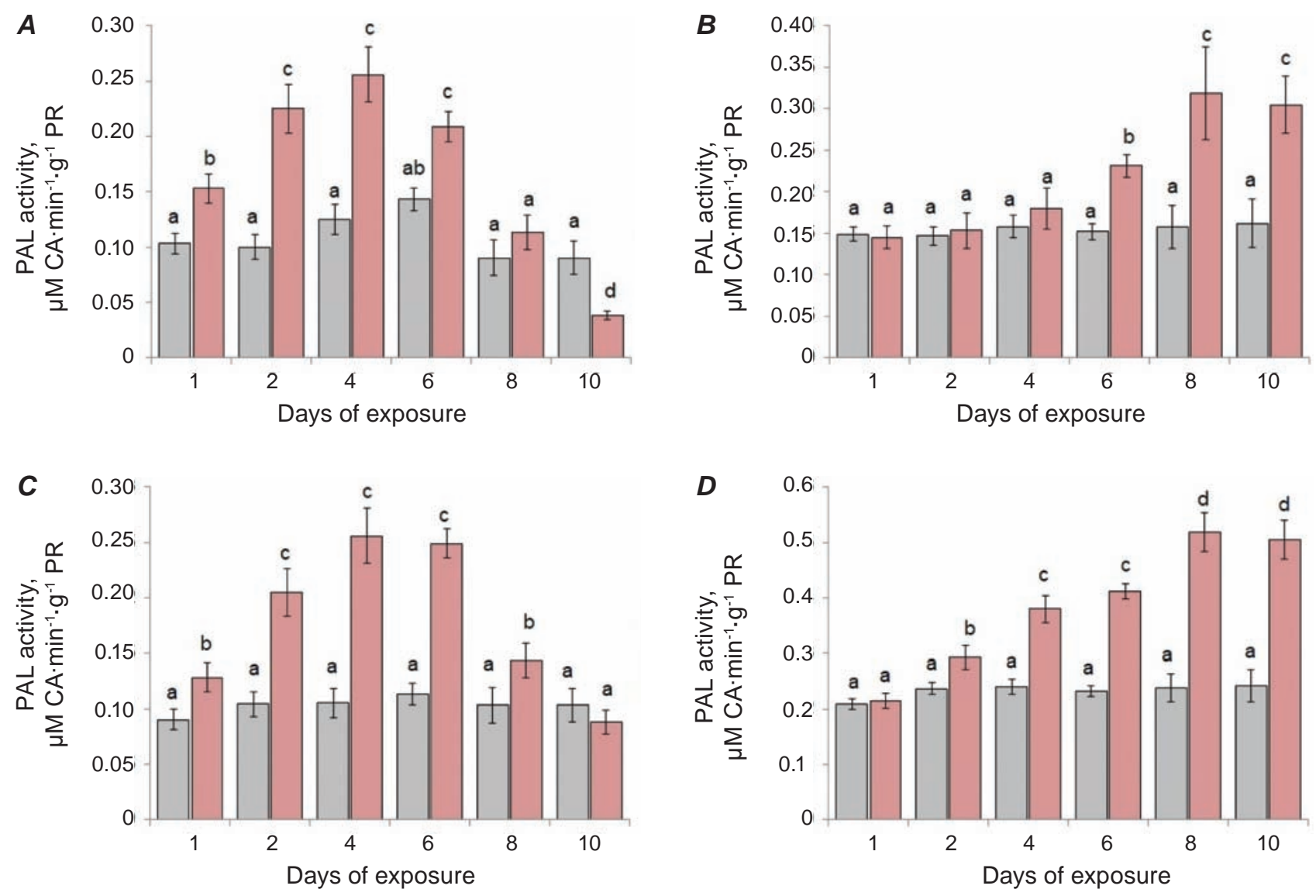

Fig. 4. Activity of phenylalanine ammonia-lyase in the root tissues (A), leaf tissues (B) of common buckwheat and root tissues (C), leaf tissues (D) of tartary buckwheat seedlings under aluminium-acid stress: $\square-$ control; $\square$-during 10 days of exposure to aluminium $(50 \mu \mathrm{M})$

with aluminum showed a gradual linear increase in the activity of enzyme from second until tenth DPE with maximum values: for eighth DPE - 218\%, and for tenth DPE - 208\% of control enzyme activity level (Fig. 4, $D$ ).

The results of the study of phenolic compounds content indicate an increase of total phenolic compounds in all investigated organs of both species of buckwheat. At the same time the increase in the content of phenylpropanoids (flavonoids and anthocyanins) was recorded only in the aboveground part of investigated seedlings. The antioxidant properties of flavonoids and anthocyanins are inextricably linked with the ability of these compounds to form stable complexes with aluminum ions [18]. Flavonoids are also known to enhance plant tolerance against different stress factors such as heavy metals. It can be explained by the involvement of anthocyanins, low molecular weight endogenous antioxidants and chelators, in the plant adaptive response processes.
Because it is known that this group of phenylpropanoids have the ability to form chelate complexes with heavy metals ions, transporting them into the vacuole for detoxification, and also affect the membrane fluidity, reducing the flow of hazardous ions into the cell [19]. This method of detoxification of toxic ions is typical for leaf tissues, where the vacuolar space of cells serves as a depot of inactivated toxic ions.

Root system of plants is first to collide with aluminium ions in the rhizosphere soil solution. Phytotoxic effect of aluminium is notable during the first minutes of exposure; root growth by cell elongation is inhibited. Root growth by cell division is stopped during the first days of the metal influence [20]. One of the mechanisms providing aluminium resistance is the secondary modification of cell walls of root cells. A number of authors noticed intensified lignification of cell walls already after the first hours of exposure [21]. Research on Oryza sativa approves strong correlation between inhibition of root growth 
and increase in salicylic acid (indusor of the lignin synthesis) content [22]. In turn intensification of root cell wall lignification - mediated by oxidative stress incorporation of phenolic compounds into a cell wall is one of the most common adaptive reactions on changes of ionic composition and $\mathrm{pH}$ level of substrate medium.

Gradual decrease in PAL activity in the root tissues that was noted in our study can be related to the start of mechanism of retrograde inhibition of the enzyme functioning by products of the reaction. Subsequent gradual increase in the PAL activity in leaves can be related to process of aluminium transport into the aboveground part of studied plants. Leaves are the storage organs in which aluminium is accumulated in the vacuole [23]. Temporary increase in a PAL activity depends on the time of plant cell contact with metal ions. Increase in activity of the enzyme responsible for synthesis of the lowmolecular antioxidants in underground and aboveground parts of the plants can be a specific adaptive reaction under aluminium-acid stress.

Conclusions. It was recorded that the addition of aluminium ions to the nutrient medium leads to the accumulation of phenolic compounds in the roots and leaves of both studied species. Analysis of the content of certain classes of phenylpropanoids showed that the most intensively accumulation of flavonoids in the leaves tissues representative both investigated species. Phenylalanine ammonia-lyase activity in the dynamics indicate the activation of this enzyme, depending on the time of action of the toxicant on the plant - in the first stages of exposure in the roots tissues and in the later stages - in the leaves tissues. Such dynamic exertion of enzyme activity is probably associated with the aluminum ions transport into vacuoles of leaf cells for internal detoxification.

Conflict of interest. Authors have completed the Unified Conflicts of Interest form at http://ukrbiochemjournal.org/wp-content/uploads/2018/12/ coi_disclosure.pdf and declare no conflict of interest.

Funding. The study was supported in part by fundamental topic of Plant biology Department of Taras Shevchenko National University of Kyiv 16КФ036-07 "Solving problematic issues of diversity and stress tolerance of representatives of Ukrainian flora and mycobiota under global climate changes" (2016-2020 academic years).

\section{ОРГАНОСПЕЦИФІЧНЕ НАКОПИЧЕННЯ ФЕНОЛЬНИХ СПОЛУК У ПРОРОСТКАХ ГРЕЧКИ ЗА ДІї АЛЮМОКИСЛОТНОГО СТРЕСУ}

\author{
О. Є. Смірнов, А. М. Косян, Ю. В. Приймак, \\ О. I. Косик, Н. Ю. Таран
}

\author{
ННЦ «Інститут біології та медицини», \\ Київський національний університет \\ імені Тараса Шевченка, Україна; \\ e-mail: plantaphys@gmail.com
}

Токсичний ефект забруднення алюмінієм $\epsilon$ однією з причин втрати врожаю цінних культур у всьому світі. Вважається, що фенольні сполуки рослин відіграють ключову роль у детоксикації алюмінію шляхом хелатування іонів алюмінію в надземній частині рослин. Однак, нещодавні дані свідчать про участь хелатних лігандів як у внутрішній, так і в зовнішній детоксикації алюмінію в рослин. Метою дослідження було визначити накопичення загальних фенольних сполук, флавоноїдів та антоціанів, а також активність фенілаланін-аміак-ліази (PAL) як ключового ензиму в синтезі фенолу в проростках гречки звичайної (Fagopyrum esculentum Moench.) та гречки татарської (Fagopyrum tataricum (L.) Gaertn.) у відповідь на алюмокислотний стрес. Додавання 50 мк $\mathrm{M} \mathrm{Al}_{2}\left(\mathrm{SO}_{4}\right)_{3} \cdot 18 \mathrm{H}_{2} \mathrm{O}$ до живильного середовища спричинювало збільшення загального вмісту фенолів в обох видах гречки у всіх аналізованих органах на десятий день експозиції рослини. Зафіксовано видо- та органоспецифічну акумуляцію певних класів фенілпропаноїдів. На десятий день дії алюмокислотного стресу активність PAL зростала в тканинах листків в обох видів гречки, проте знижувалась у тканинах коренів гречки звичайної і не змінювалась у тканинах коренів гречки татарської. Дійшли висновку, що видо- та органоспецифічність накопичення фенілпропаноїдів у досліджуваних видів $\epsilon$ адаптаційною реакцією в умовах алюмокислотного стресу.

К л ю чов в с лов а: фітотоксичність алюмінію, фенольні сполуки, фенілаланінаміак-ліаза, Fagopyrum esculentum, Fagopyrum tataricum. 


\section{References}

1. Zhu JK. Abiotic Stress Signaling and Responses in Plants. Cell. 2016; 167(2): 313-324.

2. Van Emon JM. The Omics Revolution in Agricultural Research. J Agric Food Chem. 2016; 64(1): 36-44.

3. Krishnamurthy A, Rathinasabapathi B. Oxidative stress tolerance in plants: novel interplay between auxin and reactive oxygen species signaling. Plant Signal Behav. 2013; 8(10): e25761.

4. Vighi IL, Benitez LC, Amaral MN, Moraes GP, Auler PA, Rodrigues GS, Deuner S, Maia LC, Braga EJB. Functional characterization of the antioxidant enzymes in rice plants exposed to salinity stress. Biologia Plantarum. 2017; 61(3): 540-550.

5. Nahak G, Suar M, Sahu RH. Antioxidant Potential and Nutritional Values of Vegetables: A Review. Res J Med Plants. 2014; 8(2): 50-81.

6. Babenko LM, Smirnov OE, Romanenko KO, Trunova OK, Kosakivska IV. Phenolic compounds in plants: biogenesis and functions. Ukr Biochem J. 2019; 91(3): 5-18.

7. Rahman R, Upadhyaya H. Aluminium Toxicity and Its Tolerance in Plant: A Review. J Plant Biol. 2020; 63(5). https://doi.org/10.1007/s12374-020-09280-4.

8. Yang ZB, Rao IM, Horst WJ. Interaction of aluminium and drought stress on root growth and crop yield on acid soils. Plant Soil. 2013; 372(1-2): 3-25.

9. Zhang X, Long Y, Huang J, Xia J. Molecular Mechanisms for Coping with Al Toxicity in Plants. Int J Mol Sci. 2019; 20(7): 1551.

10. Ma JF. Role of organic acids in detoxification of aluminum in higher plants. Plant Cell Physiol. 2000; 41(4): 383-390.

11. Bobo-García G, Davidov-Pardo G, Arroqui C, Vírseda P, Marín-Arroyo MR, Navarro M. Intralaboratory validation of microplate methods for total phenolic content and antioxidant activity on polyphenolic extracts, and comparison with conventional spectrophotometric methods. J Sci Food Agric. 2015; 95(1): 204-209.

12. Babenko LM, Vodka MV, Akimov YuN, Smirnov AE, Babenko AV, Kosakovskaya IV. Specific features of the ultrastructure and biochemical composition of Triticum spelta L. leaf mesophile cells in the initial period of stress temperature action. Cell Tissue Biol. 2019; 13(1): 70-78.
13. Li X, Kim JK, Park SY, Zhao S, Kim YB, Lee S, Park SU. Comparative analysis of flavonoids and polar metabolite profiling of Tanno-original and Tanno-high rutin buckwheat. J Agric Food Chem. 2014; 62(12): 2701-2708.

14. Jaleel CA, Wang G, Ahmad P. Changes in the photosynthetic characteristics of Catharanthus roseus $\mathrm{L}$. as a result of exogenous growth regulators. Plant Omics J. 2009; 2(4): 169-174.

15. Zucker M. Induction of Phenylalanine Deaminase by Light and its Relation to Chlorogenic Acid Synthesis in Potato Tuber Tissue. Plant Physiol. 1965; 40(5): 779-784.

16. Smirnov OE, Kosyan AM, Kosyk OI, Taran NYu. Response of phenolic metabolism induced by aluminium toxicity in Fagopyrum esculentum Moench. plants. Ukr Biochem J. 2015; 87(6): 129-135.

17. Bradford MM. A rapid and sensitive method for the quantitation of microgram quantities of protein utilizing the principle of protein-dye binding. Anal Biochem. 1976; 72(1-2): 248-254.

18. Procházková D, Boušová I, Wilhelmová N. Antioxidant and prooxidant properties of flavonoids. Fitoterapia. 2011; 82(4): 513-523.

19. Kosyk OI, Khomenko IM, Batsmanova LM, Taran NYu. Phenylalanine ammonia-lyase activity and anthocyanin content in different varieties of lettuce under the cadmium influence. Ukr Biochem J. 2017; 89(2): 85-91.

20. Jaskowiak J, Tkaczyk O, Slota M, Kwasniewska J, Szarejko I. Analysis of aluminum toxicity in Hordeum vulgare roots with an emphasis on DNA integrity and cell cycle. PLoS One. 2018; 13(2): e0193156.

21. Liu Q, Yang JL, He LS, Li YY, Zheng SJ. Effect of aluminum on cell wall, plasma membrane, antioxidants and root elongation in triticale. Biologia Plantarum. 2008; 52(1): 87-92.

22. Zhu CQ, Hu WJ, Cao XC, Zhu LF, Bai ZG, Huang J, Liang QD, Jin QYu, Zhang JH. Role of salicylic acid in alleviating the inhibition of root elongation by suppressing ethylene emission in rice under $\mathrm{Al}$ toxicity conditions. Plant Growth Regul. 2020; 90(3): 475-487.

23. Wang $H$, Chen RF, Iwashita $T$, Shen RF, Ma JF. Physiological characterization of aluminum tolerance and accumulation in tartary and wild buckwheat. New Phytol. 2015; 205(1): 273-279. 